\title{
Distracción osteogénica alveolar: una alternativa en la reconstrucción de rebordes alveolares atróficos
}

\author{
Alveolar distraction osteogenesis: an alternative in the reconstruction of atrophic alveolar ridges
}

La aparición de la distracción osteogénica como arma terapéutica en el tratamiento del proceso alveolar atrófico ha supuesto, por un lado el acercamiento al clínico de las técnicas reconstructivas dada su menor complejidad técnica e índice de complicaciones en relación a otras técnicas habitualmente utilizadas, y por otro,la apertura de nuevas líneas de investigación en el campo de la implantología y la reconstrucción del esqueleto facial tras traumatismos, tumores o malformaciones, como en el caso de pacientes fisurados. La utilización de los diferentes tipos de distractores se encuentra condicionada por no sólo la indicación quirúrgica sino también por el hábito del equipo que realiza el tratamiento, especialmente en el caso de los distractores intraóseos e implantes distractores, cuyos resultados están plenamente contrastados en la literatura, si bien cuentan con limitaciones de aplicación más fáciles de solventar en el caso de utilizar distractores yuxtaóseos, aunque como ventaja debemos señalar que en algunos casos son aptos para llevar a cabo la rehabilitación protésica sobre el propio dispositivo. ${ }^{1}$

La experiencia relatada en este artículo, muestra los excelentes resultados obtenidos en diversas indicaciones como muestra de la versatilidad de la técnica, ahora bien tenemos que añadir la posibilidad de realizar un aumento en espesor mediante la utilización de distractores transversales o multidireccionales, ${ }^{2-4}$ o utilizando una distracción vertical a expensas de la basal y desechando la porción más coronal, que puede ser utilizada como injerto particulado en caso de precisar técnicas complementarias.

En cuanto al protocolo, comúnmente aceptado, las principales variaciones descritas por los diversos grupos de trabajo se encuentran en la técnica e instrumental utilizados en la osteotomía, (fase quirúrgica en la que hemos introducido recientemente la cirugía piezoeléctrica, lo que aporta mayor seguridad especialmente en la vecindad de tejidos nobles), 5,6 y en el momento de iniciar la fase implantológica siendo la tal y como describen los autores, retirada del distractor y colocación simultánea de los implantes, lo que supone un ganancia de tiempo con respecto a las técnicas tradicionales, pues el implante se integra durante la fase de maduración del callo, permitiendo su carga precoz. ${ }^{7}$

A la vista de éste y otros artículos sobre el tema, podemos concluir que la distracción aplicada a la reconstrucción del proceso alveolar abre un amplio abanico de posibilidades tanto como técnica individual como combinada con las reconstrucciones consideradas «tradicionales».

A. Bilbao Alonso
Doctor en Medicina y Cirugía.
Facultativo Especialista de Área. Cirugía Oral y Maxilofacial. España.
Complejo Hospitalario Universitario. Santiago de Compostela. Práctica
privada La Rosaleda Hospital Policlínico.
Santiago de Compostela. España

A. Bilbao Alonso

Facultativo Especialista de Área. Cirugía Oral y Maxilofacial. España. privada La Rosaleda Hospital Policlínico. Santiago de Compostela. España
The appearance of osteogenic distraction as a therapeutic arm in the treatment of the atrophic alveolar condition has meant, on the one hand, the approach of reconstructive techniques to the clinician given its lower technical complexity and complications index in relationship to other commonly used techniques and, on the other, the opening of new research lines in the field of implantology and facial skeleton reconstruction after traumatisms, tumors, or malformations such as in the case of patients with a cleft lip.

The use of different types of distractors and distractor implants is conditioned not only by surgical indication but also by the habit of the team performing the treatment, especially in the case of intraosseous distractors and distractor implants, whose results are fully contrasted in the literature, although they have easier application limitation to solve in the case of using juxtaosseous distractors. However, as an advantage, we should mention that they are adequate to carry out prosthetic rehabilitation on the device in some cases. ${ }^{1}$

The experience presented in this article shows the excellent results obtained in several indications as is shown by the versatility of the technique, however, we must add the possibility of increasing the thickness with transversal or multidirectional distractors ${ }^{2-4}$ or using a vertical distraction at the expense of the baseline and eliminating the most coronal portion, that can be used as a particulated graft if complementary techniques are required.

In regards to the commonly accepted protocol, the main variations described by the different work groups are found in the technique and instrumental used in the osteotomy (surgical phase in which we have recently introduced the piezoelectric surgery, which contributes better safety, especially in the area of the important tissues) $)^{5,6}$ and in the time of initiating the implantological phase, the withdrawal of the distractor and simultaneous placement of the implants being as is described by the authors. This means a gain in time in regards to the traditional techniques since the implant is integrated during the callus maturity phase, permitting early loading. ${ }^{7}$

Based on this and other articles on the subject, we can conclude that the distraction applied to the reconstruction of the alveolar process opens a wide range of possibilities including individual as well as combined technique with the reconstructions that are considered «traditional». 


\section{Bibliografía}

1. Gaggl A, Schultes $G$, Karcher H. Vertical alveolar ridge distraction with prosthetic treatable distractors: a clinical investigation. Int J Oral Maxillofac Implants 2000;15:701-10.

2. Watzek G, Zechner W, Crismani A, Zauza K: A distraction abutment system for 3-dimensional distraction osteogenesis of the alveolar process: technical note. Int J Oral Maxillofac Implants 2000;15:731-7.

3. Aparicio $C$, Jensen OT. Alveolar ridge widening by distraction osteogenesisa case report. Pract Proced Aesthet Dent 2001;13:663-8.

4. Kitano S, Wada K, Komori T. Endosseus implants in horizontal alveo- lar ridge distraction osteogenesis. Nosaka Y. Int J Oral Maxillofac Implants 2002;17:846-53.

5. Vercellotti T, De Paoli S, Nevins M. The piezoelectric bony window osteotomy and sinus membrane elevation: introduction of a new technique for simplification of the sinus augmentation procedure. Int I Periodontics Restorative Dent 2001;21:561-7.

6. Vertellotti T. Piezoelectric Surgery in implantology: a case report-a new piezoelectric ridge expansion technique. Int I Periodontics Restorative Dent 2000;20:358-65.

7. Consolo U, Bertoldi C, Urbani G, Zaffe D. Clinical evaluation, radiologic and histologic análisis in mandibular alveolar distraction procedures. Preliminary study. Minerva Stomatol 2000;49:475-84. 